Научная статья

УДК 340.115 .6

DOI $10.18101 / 2658-4409-2021-4-23-28$

\title{
О НЕКОТОРЫХ ОСОБЕННОСТЯХ НАУЧНЫХ ВЗГЛЯДОВ Л. Я. ШТЕРНБЕРГА
}

\section{(C) Илтакова Наталья Владимировна}

кандидат исторических наук, старший преподаватель, Бурятский государственный университет имени Доржи Банзарова Россия, 670000, г. Улан-Удэ, ул. Сухэ-Батора, 6 ulynpa@mail.ru

\author{
(C) Копалкина Евгения Геннадьевна \\ кандидат философских наук, доцент, \\ Байкальский государственный университет \\ Россия, 664003, г. Иркутск, ул. Ленина, 11 \\ kopalkina2017@list.ru
}

\begin{abstract}
Аннотация. Л. Я. Штернберг - выдающийся ученый-этнограф, посвятивший себя исследованию нивхов, тунгусо-маньчжуров, айнов, основатель Ленинградской этнографической школы, заместитель директора Музея антропологии и этнологии имени Петра Великого, один из основателей этнографического отделения Географического института в Ленинградском университете. Статья посвящена истории биографического описания творческого пути ученого-этнографа Л. Я Штернберга. Цель работы иметь представление о научных взглядах Л. Я. Штернберга. Авторы рассматривают возможности биографического метода, построенного на биографии, событиях, которые оказали влияние на научные взгляды учёного.
\end{abstract}

Ключевые слова: Штернберг, этнография, антропология, народы Сахалина, Джезуповская экспедиция.

\section{Для цитирования}

Илтакова Н. В., Копалкина Е. Г. О некоторых особенностях научных взглядов Л. Я. Штернберга // Вестник Бурятского государственного университета. Юриспруденция. 2021. Вып. 4. С. 23-28.

В конце XIX в. в России интеллигенция, студенты, недовольные политикой самодержавия, принимают участие в революционной организации «Народная воля». После серии террористических акций против правительства участников движения отправляют в ссылку в Сибирь.

Студенты Петербургского, Харьковского, Московского, Варшавского, Берлинского университетов волею судьбы оказались в Иркутской губернии, Якутской области, Забайкальской губернии и на Сахалине.

Молодые образованные люди посвятили свое время изучению языка, фольклора, религии местного населения. Во время ссылки они собрали и подготовили к публикации богатый этнографический материал о языке, фольклоре, верованиях коренных народов Сибири и Дальнего Востока.

Важную роль в изучении народов Севера, Сибири и Дальнего Востока сыграли Владимир Германович Богораз (Тан), Владимир Ильич Иохельсон, Лев Яковлевич Штернберг, Эдуард Карлович Пекарский, Иван Иванович Майнов, Сергей 
Васильевич Ястремский, Николай Алексеевич Виташевский, Дмитрий Александрович Клеменц, Моисей Ааронович Кроль, Вацлав Леопольдович Серошевский, Бронислав Пилсудский.

Основателями Лениградской этнографической школы стали Владимир Германович Богораз (Тан) и Лев Яковлевич Штернберг.

Будучи студентом физико-математического факультета Петербургского университета и потом юридического факультета, Л. Я. Штернберг принимал участие в революционной деятельности. За активное участие в партии «Народная воля» он был арестован в 1886 г. и весной 1889 г., после трехлетней «отсидки» в Одесской центральной тюрьме, выслан на десятилетнее поселение на остров Сахалин, где и началась его этнографическая работа [1, с. 11].

Лев Яковлевич одним из первых занимался изучением нивхского языка. Особый интерес для ученого представляли семья и брак, религиозные верования, фольклор нивхов.

Когда Л. Я. Штернберг вернулся из ссылки, он подготовил к публикации свою работу «Образцы материалов по изучению гиляцкого языка и фольклора». Oceнью 1899 г. ему предложили место младшего этнографа в Музее антропологии и этнографии Академии наук.

Для понимания взглядов Л. Я. Штернберга следует учитывать не только его ранние опубликованные работы, где он разделяет взгляды эволюционистов Л. Г. Моргана и Э. Тайлора, но и поздние публикации, где заметно влияние новых научных теорий. Лев Яковлевич познакомился и вел переписку с родоначальником американской антропологии Францом Боасом, который искал в России этнографов, специалистов по народам Сибири и Дальнего Востока, чтобы они смогли принять участие в организованной им экспедиции. Он обратился с просьбой к директору Музея этнографии при Императорской СанктПетербургской академии наук Василию Радлову. Это была экспедиция, финансируемая Моррисом Джезупом. Радлов рекомендовал Иохельсона, Владимира Богораза и Льва Штернберга.

Целью этой обширной научно-исследовательской компании, собравшей несколько групп на общий срок пять лет (1897-1902) и непосредственно в Сибирь на период два года (1900-1902), было изучение возможных связей между народами Северо-Восточной Азии и Северо-Западной Америки в области археологии, фольклора, языков, искусства, материальной культуры и физической антропологии [2].

Джезуповская экспедиция сыграла исключительно важную роль в формировании не только американской, но и российской антропологической науки, прежде всего сибире- и североведения - этнографии, фольклористики и лингвистики коренного населения Крайнего Севера [3, с. 242].

Всестороннее исследование народов Сибири и Дальнего Востока стало возможным также благодаря Францу Боасу, который в письмах Джезупу писал, что исследование о взаимовлиянии древних культур азиатской части северного побережья Тихого океана от реки Амура до Берингова пролива показало с несомненностью, что существуют определенные культурные элементы, общие для всех племен региона. Луки, доспехи, способы изготовления лодок могут служить примерами. Мифологии племен этого обширного региона также демонстрируют элементы сходства, свидетельствующие о ранних контактах. Отмечены близкие 
параллели между фольклором Сибири и Британской Колумбии, в особенности сказки, собранные у айнов Йеццо (о-в Хоккайдо), камчадалов и индейцев о-ва Ванкувер. Однако этот вопрос ни в коем случае не может считаться окончательно решенным, да и не может быть решен без глубокого изучения всех племен этого регионах [3, с. 247].

Ф. Боас интересовался изучением языков, пытался найти структурное сходство между языками народов Восточной Сибири и Дальнего Востока с языками народов Америки.

В январе 1898 г. Ф. Боас в письме В. В. Радлову писал: «На весну этого года мы запланировали экспедицию в низовья Амура. Мы запросили и получили разрешение от Правительства Российской Империи проводить исследования в этом районе, и я пригласил д-ра Бертольда Лауфера из Кельна, который изучал азиатские языки в университетах Берлина и Лейпцига, заняться изучением языка гиляков $<\ldots>$ Я ищу молодого человека, который согласился бы провести год или два в северо-восточной Сибири, имея в виду, что он займется изучением обычаев, уклада, языков и физических характеристик населения этого района» $[3$, c. 253$]$.

Ф. Боасу были необходимы сведения о населении северного побережья Тихого океана - чукчах, коряках и нивхах. Иохельсон согласен был ехать «только к юкагирам», в конце концов он согласился ехать к корякам. Богораз «бунтовал» похожим образом: он предложил маршрут, который не соответствовал задачам Джезуповской экспедиции. Богораза интересовали приморские чукчи (и эскимосы) [3, с. 265].

Л. Я. Штернберг непосредственного участия в Джезуповской экспедиции не принимал. Ф. Боас заказал ему монографию по нивхам для серии публикаций Джезуповской экспедиции $[4$, c. 53$]$.

С 1900 г. Лев Яковлевич стал редактором этнографического словаря Брокгауза и Ефрона, с 1901 г. начал сотрудничать с одним из крупнейших научных учреждений Российской империи в сфере народоведения - Музеем антропологии и этнографии, где в 1904 г. занял должность старшего этнографа, заместителя директора. Им были написаны общий обзор инородцев в России, а также статья, посвященная бурятам [1, с. 268].

С 1918 г. Штернберг фактически возглавил МАЭ, в том же году Лев Яковлевич возглавил этнографическое отделение Географического института в Петрограде.

В. Г. Богораз отмечал: «Радлов и Штернберг в полтора десятилетия собрали для музея большую половину наличных коллекций и сборов. Особенно в последние годы, перед самой войной, их работа по организации научных экспедиций, можно сказать, во все области и материки земного шара, развернулась с большой широтой. Мировая война застала экспедиции Музея в таких удаленных друг от друга местах, как Южная Америка, Индия и Восточная Азия [5, с. 81].

Также при содействии Л. Я. Штернберга и В. Г. Богораза в 1924 г. был создан Комитет содействия народностям северных окраин при Президиуме ВЦИК (Комитет Севера), в рамках которого не только изучался быт северных народов, но и была начата подготовка национальных кадров, продолжившаяся потом в рамках Института народов Севера, основанного в 1929 г. Целью функционирования института было не просто обучение нескольких десятков представителей северных 
народов, но и создание такой системы, при которой эти обучающиеся будут выступать в качестве агентов модернизации. Подразумевалось, что они будут сочетать теоретическое обучение в институте с ежегодными поездками домой, в рамках которых смогут проводить полевые исследования и личным примером продемонстрировать сородичам те возможности, которые дает им советская власть.

Лев Яковлевич Штернберг создал курс по истории религии, основанный на собственных этнографических наблюдениях. В нем доказывалось отсутствие дорелигиозного периода в истории человечества, а сама религия была названа древнейшим общественным институтом. Само определение религии, данное Штернбергом, существенно отличалось от тех, которые использовались прежде: «Религия есть одна из форм борьбы за существование в той области, где личные усилия человека, все усилия его интеллекта, все его гениальные способности и изобретательность являются бессильными» [6, с. 271].

Сергей Кан, профессор антропологии Dartmouth College, специалист по культуре и истории тлинкитов, русских миссионеров на Аляске, методологии и этике этнографических исследований североамериканских индейцев, биограф Л. Штернберга, писал: «20-е годы могут быть названы золотым веком антропологии в Советском Союзе». В этот период существовало две школы российских этнографов и антропологов: московская под руководством Д. Н. Анучина и ленинградская, созданная усилиями Л. Я. Штернберга и В. Г. Богораза. Этими учеными была воспитана целая плеяда учеников, чьи труды легли в основу российской и мировой антропологии, этнографии, языковедения и искусствоведения аборигенов Дальнего Востока. Среди них антропологи М. Г. Левин и Г. Ф. Дебец, ученики Л. Я Штернберга: лингвисты Г. М. Василевич, В. А. Авронин, Е. А. Крейнович, В. И. Цинциус, этнографы Н. Г. Каргер, И. И. Козьминский, А. Н. Липский, искусствовед С. В. Иванов и многие другие [8, с. 161-162].

С. Кан рассмотрел теоретические взгляды Штернберга в широком контексте не только российской, но и зарубежной антропологии. Это позволило нарисовать картину не столь однозначную, но более сложную и интересную.

Более внимательное и менее догматичное чтение этнографических текстов Л. Я. Штернберга по общей и сравнительной этнографии позволили С. Кану показать, что его эволюционизм сочетается с другими взглядами. В ранних статьях, например, с «народническим идеализмом». В более поздних работах (С. Кан интересно и подробно разбирает опубликованные и неопубликованные тексты его лекций) - не только с утопическим социализмом, но и с идеями Ф. Боаса, приверженностью иудаизму. С. Кан показывает, как научное мировоззрение Л. Я. Штернберга видоизменялось в силу открытости ученого для новых методов и идей, популярных на Западе в 1910-1920-е гг. В последних статьях ученого («Избранничество в религии», «Айнская проблема») С. Кан нашел отзвуки идей антропологов-диффузионистов и даже представителей психологической антропологии - Р. Бенедикт и Э. Сэпира [7, с. 333].

Известно, что краткий отчет Штернберга по терминологии родства и брачной системы нивхов дал Ф. Энгельсу конкретные доказательства его эволюционной теории истории человеческой семьи. Энгельс настаивал, что родственная терминология нивхов указывала на существование группового брака между братьями и сестрами из двух кланов и так называемой семьи пуналуа. Тем не менее детальное описание Штернберга привело антропологов к другой теоретической модели. 
Это была обобщенная модель обмена в брачной и родственной структуре [9, c. 292, 295].

Влияние Штернберга на мировую антропологию не ограничивалось только примером эволюционной антропологии. Его статью о брачной системе нивхов позже цитировал К. Леви-Стросс в качестве примера обобщенной модели обмена женщинами и калыма между родственными группами

Вопросы семьи и брака, возникновение первых форм социальной организации, которым уделял особое внимание Лев Яковлевич, не теряют своей актуальности в настоящее время. Трансформация брака и семьи, которую мы сейчас видим, является трансформацией человека в иное разумное существо. В связи с этим актуальными являются научные работы, посвященные формам, эволюционным и культурным особенностям семьи.

\section{Литература}

1. Штернберг Л. Я. Гиляки, орочи, гольды, негидальцы, айны. Хабаровск, 1933. С. 11. Текст: непосредственный.

2. Калиновски И. Владимир Иохельсон, Франц Боас и Сибирь // Сибирь как поле межкультурных взаимодействий: литература, антропология, историография, этнология. Москва, 2021. С.181. Текст: непосредственный.

3. Вахтин Н. Тихоокеанская экспедиция Джесупа и ее русские участники // Антропологический форум. Санкт-Петербург, 2005. С. 242. Текст: непосредственный.

4. Арзютов Д. В., Кан С. А. Концепция поля и полевой работы в ранней советской этнографии // Этнографическое обозрение. 2013. № 6. С. 53. Текст: непосредственный.

5. Панченко А. Б. От общего к частному и обратно: особенности производства знания народниками // Философия. Журнал Высшей школы экономики. 2020. Т. 4, № 2. С. 268. Текст: непосредственный.

6. Корсун С. А. Л. Я. Штернберг как американист // Лев Штернберг - гражданин, учёный, педагог. Санкт-Петербург: МАЭ РАН, 2012. С. 81. Текст: непосредственный.

7. Михайлова Е. А. Рец.на кн: Sergei Kan Lev Shternberg: Antropologist, Russian Socialist, Jewish Activist // Антропологический форум. 2011. № 15. С. 329-330. Текст: непосредственный.

8. Осипова М. В. Этнографические экспедиции на территории Хабаровского края в первые годы советской власти // Лев Штернберг - гражданин, ученый, педагог. СанктПетербург: МАЭ РАН, 2012. С. 161-162. Текст: непосредственный.

9. Сиро Сасаки Исследование Л. Я. Штернбергом нивхского общества и структурная антропология // Лев Штернберг - гражданин, учёный, педагог. Санкт-Петербург: МАЭ РАН, 2012. С. 292, 295. Текст: непосредственный.

Статья поступила в редакцию 26.11.2021; одобрена после рецензирования 29.11.2021; принята к публикации 14.12.2021. 
ON SOME PECULIARITIES OF L. YA. STERNBERG'S SCHOLARLY VIEWS

Natalya V. Iltakova

Cand. Sci. (History),

Senior Lecturer of Theory and History of Law and State Department, Dorzhi Banzarov Buryat State University

24a Smolina St., Ulan-Ude 670000, Russia

ulynpa@mail.ru

Evgeniya G. Kopalkina

Cand. Sci. (Philosophy), A/Prof.

of Sociology and Psychology Department,

Baikal State University

11 Lenina St., Irkutsk 664003, Russia

kopalkina2017@list.ru

Abstract. L. Ya. Sternberg is an outstanding ethnographer who devoted himself to the study of the Nivkhs, Tungus-Manchus, Ainu, he is the founder of Leningrad Ethnographic School, Deputy Director of the Peter the Great Museum of Anthropology and Ethnology, and one of the founders of Ethnographic Department of Geographic Institute at Leningrad University. The article deals with the biography, career and scholarly views of L. Ya. Sternberg. We have considered the possibilities of the biographical method, based on biography, and events that influenced the scholarly views of the scientist.

Keywords: L. Ya. Sternberg, ethnography, anthropology, the peoples of Sakhalin, Dzhezupov expedition.

For citation

Iltakova N. V., Kopalkina E. G. On Some Peculiarities of L. Ya. Sternberg's Scholarly Views. Bulletin of Buryat State University. Law. 2021; 4: 23-28 (In Russ.).

The article was submitted 26.11.2021; approved after reviewing 29.11.2021; accepted for publication 14.12.2021. 